Discussion

Papers

Statistics Norway

Research department

No. 863

August 2017

Tony Atkinson and his legacy

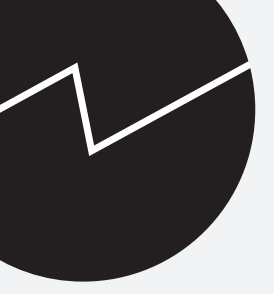

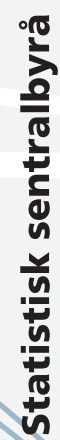





\title{
Tony Atkinson and his legacy
}

\author{
Rolf Aaberge, François Bourguignon, Andrea \\ Brandolini, Francisco H. G. Ferreira, Janet C. Gornick, \\ John Hills, Markus Jäntti, Stephen P. Jenkins, Eric \\ Marlier, John Micklewright, Brian Nolan, Thomas \\ Piketty, Walter J. Radermacher, Timothy M. Smeeding, \\ Nicholas H. Stern, Joseph Stiglitz, Holly Sutherland
}

\begin{abstract}
:
Tony Atkinson is universally celebrated for his outstanding contributions to the measurement and analysis of inequality, but he never saw the study of inequality as a separate branch of economics. He was an economist in the classical sense, rejecting any sub-field labelling of his interests and expertise, and he made contributions right across economics. His death on 1 January 2017 deprived the world of both an intellectual giant and a deeply committed public servant in the broadest sense of the term. This collective tribute highlights the range, depth and importance of Tony's enormous legacy, the product of over fifty years' work.
\end{abstract}

Acknowledgements: Prepared for the Review of Income and Wealth

Address: Rolf Aaberge, Statistics Norway, Research Department Department of Economics, University of Oslo. E-mail: roa@ssb.no

François Bourguignon, Paris School of Economics Andrea Brandolini, DG Economics, Statistics and Research, Bank of Italy Francisco H. G. Ferreira, Development Economics Research Group, The World Bank Janet C. Gornick, LIS and The Graduate Center, City University of New York John Hills, London School of Economics Markus Jäntti, Swedish Institute for Social Research, Stockholm University Stephen P. Jenkins, London School of Economics Eric Marlier, Luxembourg Institute of Socio-Economic Research (LISER) John Micklewright, University College London Brian Nolan, University of Oxford Thomas Piketty, Paris School of Economics Walter J. Radermacher, Former Director General of Eurostat Timothy M. Smeeding, University of Wisconsin-Madison Nicholas H. Stern, London School of Economics Joseph Stiglitz, Columbia University Holly Sutherland, Institute for Social and Economic Research, University of Essex 
comprise research papers intended for international journals or books. A preprint of a Discussion Paper may be longer and more elaborate than a standard journal article, as it may include intermediate calculations and background material etc.

(c) Statistics Norway

Abstracts with downloadable Discussion Papers

in PDF are available on the Internet:

http://www.ssb.no/en/forskning/discussion-papers

http://ideas.repec.org/s/ssb/dispap.html

ISSN 1892-753X (electronic) 


\section{Forord}

Anthony (Tony) Barnes Atkinson døde 1. januar 2017. Det er et betydelig tap for det internasjonale økonomimiljøet og ikke minst for de av oss som kjente han og hadde gleden av å samarbeide med han. Men Tony Atkinson etterlater seg også en enorm faglig arv, som er produktet av over femti års arbeid. Denne artikkelsamlingen, skrevet av sytten forfattere, forsøker å bringe fram både bredden, dybden og betydningen av arven etter Tony Atkinson. Artiklene blir publisert i et kommende spesialnummer av tidsskriftet Review of Income and Wealth. Statistisk sentralbyrå har fått tillatelse fra redaktøren av Review of Income and Wealth til å publisere artikkelsamlingen i serien Discussion Papers.

Tony Atkinsons mye omtalte og siterte 1970-artikkel (publisert i Journal of Economic Theory) om måling av inntektsulikhet forandret hvordan økonomer tenker omkring måling av ulikhet, og har dannet grunnlaget for moderne teoriutvikling og empiriske analyser om ulikhet. Denne artikkelen var mitt første møte med Tony. Den gjorde et uutslettelig inntrykk, ikke minst på grunn av kombinasjonen av matematisk stringens og presist språk.

Beundringen av 1970-artikkelen ble senere til beundring av forfatteren. Det startet med en invitasjon i 2007 om å samarbeide om et bokkapittel om toppinntektene i Norge. Dette prosjektet ble starten på et langsiktig samarbeid, som førte til at Tony ble ansatt i bistilling i SSB der han blant annet deltok i flere økonomisk historiske prosjekter sammen med meg og Jørgen Modalsli. Hans mange besøk i SSB ga oss gode muligheter til å bli bedre kjent med både Tonys faglige og menneskelige sider. Ett av våre felles prosjekter foreslått av Tony har følgende tittel: "Sette folk først: Om politikk og økonomisk velferd". Å sette folk først er en dekkende beskrivelse av Tonys etiske sinn, holdninger og atferd, som også kommer til uttrykk i forordet til hans siste bok «Inequality: What can be done?» hvor han skriver: "Royalties received for this book before 2020 will be donated to the following charities: Oxfam, Tools for Self Reliance, Emmas UK, and the Quaker Housing Trust”.

Rolf Aaberge 


\section{Tony Atkinson - consummate scholar, by Andrea Brandolini, Stephen Jenkins and John Micklewright}

Anthony (Tony) Barnes Atkinson is universally celebrated for his outstanding contributions to the measurement and analysis of inequality in theory and in practice. But it would be reductive to confine his excellence to a single field, however fundamental. Tony was an economist in the classical sense, rejecting any label of a sub-field on his interests and expertise. He never saw the study of inequality as a separate branch of economics and always insisted on its place as an integral part of the economist's agenda. His death on 1 January 2017 deprived the world of both an intellectual giant and a deeply committed public servant in the broadest sense of the term - someone who wished to devote his prodigious skills and seemingly unbounded energy to the service of all. The passage of time will only underline that loss. But Tony also left an enormous legacy, the product of over fifty years of work. This collective article by seventeen authors tries to bring out its range, its depth and its importance.

There is no doubt that Tony's 1970 Journal of Economic Theory paper radically changed the way that economists think about the measurement of inequality, providing the starting point for the modern analysis of the subject. (Here, Tony would warn us that similar ideas had been independently advanced by Kolm in a paper published in 1969 of which he had become aware only when his own article had been accepted for publication.) He emphasised the welfare economic foundations of inequality measurement, provided the link between inequality orderings of income distributions and graphical comparison of Lorenz curves, and introduced a new class of inequality measures that makes explicit different views about distributional justice. Tony's fundamental insight was that inequality measurement cannot be seen as a purely objective statistical exercise as it is intrinsically linked to underlying normative views, a topic to which he returned throughout his life (e.g. Atkinson and Brandolini, 2010). Rolf Aaberge's discussion of this fundamental paper begins our review of Tony's legacy. This leads on naturally to discussion of Tony's research on measuring inequality and poverty in more than one dimension, much of it conducted with François Bourguignon who describes here the work's importance. Markus Jäntti then discusses Tony's pioneering work on measuring another aspect of economic inequality - the extent of intergenerational income mobility (or its lack), a topic of huge interest in recent years (summarised in e.g. Jäntti and Jenkins, 2015). Tony's co-authored monograph on the subject, Parents and Children: Incomes in Two Generations (Atkinson, Maynard and Trinder, 1983a), was far ahead of its time. (He once commented that it had the smallest print-run of any of his books!)

As Jäntti's contribution shows, Tony examined thoughtfully the data used in his analyses, using remarkable ingenuity. He painstakingly scrutinised original sources to understand whether the data were fit for the research purpose, to assess how they compared to alternative sources, to improve existing statistics or to estimate new ones. For instance, he evaluated the quality of income data collected in the UK Family Expenditure Survey (Atkinson and Micklewright, 1983) and discussed the comparability of figures on income distribution used in cross-national comparisons (Atkinson and Brandolini, 2001, 2009). He collected extensive documentation on the evidence about wealth distribution in the United Kingdom (UK) (Atkinson and Harrison, 1978), income distribution in Eastern Europe under Communism (Atkinson and Micklewright, 1992) and OECD countries (Atkinson, Rainwater and Smeeding, 1995), and earnings distribution in OECD countries (Atkinson, 2008a). His guidance and support were crucial for new endeavours. Tim Smeeding and Janet Gornick discuss the important role Tony played in encouraging and overseeing LIS (formerly known as the Luxembourg Income Study), the long-running cross-national database of harmonised microdata on household incomes, and of the key use he made of the data for OECD countries in the 1990s. Thomas Piketty analyses Tony's work on the long-run evolution of income and wealth inequality which uses income and inheritance tax returns that often stretch back for many decades. At his death, Tony was still working hard on these issues with Piketty and others, extending the 
historical analysis of top income shares to former colonial countries. Francisco Ferreira describes Tony's work in the last eighteen months of his life on global poverty when he led a commission of experts on the subject for the World Bank and wrote the commission's report (Atkinson, 2017).

Public economics is the other field where Tony left a permanent mark. As for inequality analysis, he grounded policy discussion in high theory, but the latter was never seen as a selfreferential conceptual exercise. For Tony, economics was a tool for understanding the world and taking informed decisions on policies. Economists must strive to communicate their results beyond the narrow circles of decision-makers, making them accessible for public discussion (Atkinson, 1990a). Thus, Public Economics in Action (1995a) is the title of his book devoted to explaining the pros and cons of basic income. This conviction neatly emerges in the contributions by Joseph Stiglitz, Nicholas Stern, John Hills, and Holly Sutherland (see also Sandmo, 2017). Countless graduate students, ourselves included, were brought up on Atkinson and Stiglitz's 1980 Lectures on Public Economics (re-published in 2015), which included results from their important papers together in the 1970s on optimal taxation, while the Journal of Public Economics that Tony cofounded early in the same decade and then edited with Stern quickly became the leading journal in the field. Stiglitz recalls their efforts to explain the limits of the implication of their 1976 paper that there should be no taxes on interest. This point echoes a recent remark by Tony: "The result we stated was not a recommendation for zero capital taxation but the delineation of a benchmark by which we can understand the conditions under which taxation is, or is not, desirable.... While the Atkinson-Stiglitz result has been correctly interpreted by careful users ..., it has been much misused as a blanket support for zero capital taxation” (Atkinson, 2014, 40). This is a telling example of Tony's approach to economic theorising. Hills describes key features of Tony's analysis of the welfare state in his lifelong concern with policies to combat poverty and reduce inequality - although Hills is at pains to point out that in Tony's 2015 opus magnum, Inequality: What can be done?, he placed much emphasis on the need to alter the pre-tax and benefit distribution of incomes as well. Microsimulation models that show the distributional impact of tax and benefit changes on representative household samples are an important tool to illustrate policy change to the general public - and one used by Tony in his 2015 book with the assistance of Sutherland and colleagues. Sutherland underlines Tony's part in establishing the long-running microsimulation model for the European Union (EU), EUROMOD.

Tony was a passionately committed European and other aspects of his work on "Social Europe" are discussed by Eric Marlier and Brian Nolan. These range from intellectual contributions to the measurement and analysis of poverty and social exclusion, such as his Yrjö Jahnsson lectures published in the excellent little volume Poverty in Europe (1998), to his work with Marlier, Nolan and Bea Cantillon on social indicators for the EU, to his advice and support of Eurostat, described in the final contribution to this article by Walter Radermacher who considers Tony's contribution to the field of official statistics. Tony learned his national accounts as an undergraduate (he used to lament their absence from the current economics curriculum) and Radermacher describes the influence of his work for the UK Treasury on the measurement of government output for national accounting in Europe.

Several themes recur in the contributions assembled in this article. There is Tony's scrupulous attention to data quality and his determination to seek out relevant data sources. There is his appreciation of history; his prescience, working on topics before they became fashionable; and there is his insistence on going back to basic principles and carefully working through their various implications for the task in hand, un-blinkered by pre-conceptions, often using relatively simple models to think through the grammar of issues and guide our thinking. There is his call for "a more systematic interconnection between economic analysis in general and distribution issues" (Atkinson and Bourguignon, 2000a, 4). Tony’s presidential lecture to the Royal Economic Society on "Bringing income distribution in from the cold" (Atkinson, 1997) is but one exemplar of all his qualities and interests: there is a concern with integrating inequality into the heart of economics; the 
deployment of models that explore the roles of factors not receiving sufficient attention in conventional approaches; careful examination of data (also employing a historical perspective); and the important substantive finding about the episodic nature of inequality trends.

The different contributions demonstrate the wide range of Tony's work, including his many collaborations with other scholars, but they are not exhaustive. (See Jenkins, 2017, for a more comprehensive overview and Tony's website at http://www.tony-atkinson.com/ for a complete list of publications and other information.) Here we want only to note that Tony's first two academic articles were in macroeconomics, which may come as a surprise to some readers. One stressed that research on growth models was overlooking the speed of convergence to the long-run equilibrium, despite this being a significant prediction of the models: "If we throw away information about the time dimension, we are reducing still further our limited understanding of the relationship between these models and the real world" (Atkinson, 1969b, 137). Tony questioned steady-state assumptions in later work as well (Atkinson and Jenkins, 1984).

Tony's other macroeconomics article suggested that technical progress does not apply across the board, as usually postulated, but specifically to particular techniques of production; hence, technical development is localised and history matters (Atkinson and Stiglitz, 1969). Daron Acemoglu recently noted that this idea "was ahead of its time in emphasising localised and biased new technologies and challenging the orthodoxy in the modelling of technological change" (2015, 456).

These two articles from the start of his career in the late 1960s show salient features of Tony's future research: the effort to work out all the implications of theoretical models; a willingness to explore analytical solutions different from the received one; and awareness of the limits of models. "Economists are too often prisoners within the theoretical walls they have erected", he recently wrote while discussing austerity policies, "and fail to see that important considerations are missing" (Atkinson, 2014, 84).

Tony avoided boxing himself in and he had the ability to see over the tops of the walls others had constructed. Shortly before his death, he wrote in an unfinished manuscript for a book on global poverty that he was on a "steep learning curve”. Part of Tony's legacy is his example of openness and humility in the pursuit of knowledge. 


\section{Inequality measurement, by Rolf Aaberge}

Tony's 1970 article in the Journal of Economic Theory (Atkinson, 1970) was my first encounter with Tony. It made an indelible impression, not least due to the paper's combination of precise language and mathematical rigour. This paper dealt with the conceptual problems involved in the measurement of inequality and offered a convincing justification for constructing measures of inequality on the basis of a social welfare function. Tony referred to the pioneering paper by Hugh Dalton (1920) as a major source of inspiration. Dalton was critical of the standard practice of measuring economic inequality as physicists and biologists measured the dispersion in distributions of physical variables. He motivated his paper as follows: "For the economist is primarily interested, not in the distribution of income as such, but in the effects of the distribution of income upon the distribution and total amount of economic welfare, which may be derived from income" $(1920,348)$. Thus, Dalton treated income as a determinant of economic welfare and defined social welfare as the sum of individuals' welfare or utility. (For an extensive discussion of Dalton's paper see Atkinson and Brandolini, 2015.)

The utilitarian motivation underlying Dalton's social welfare approach confused Corrado Gini who wrote: "The methods of Italian writers, which are explained by Mr. Dalton, are not, as a matter of fact, comparable to his own, inasmuch as their purpose is to estimate, not the inequality of economic welfare, but the inequality of incomes and wealth ...” $(1921,124)$. Unfortunately, Gini never got the opportunity to read Tony's 1970 paper, where Tony, as opposed to Dalton, did not define the social welfare function as the sum of individual utility levels, but directly as a function of individuals' incomes. (This direct approach has also inspired recent advances in preference aggregation for multidimensional settings, e.g. Piacquadio, forthcoming.) Indeed, Tony was, like Gini, concerned with the measurement of income inequality. However, in contrast to Gini, Tony argued that underlying any measure of income inequality "is some concept of social welfare and it is with this concept that we should be concerned”. (As later demonstrated by Weymark, 1981, and Yaari, 1987, the Gini coefficient and the family of rank-dependent measures of inequality have an equally convincing social welfare justification as the measures introduced by Tony.) Tony made an explicit parallel with the problem of choice under risk. Even though it was not stated in his paper, this means that the ranking of income distributions can be given a similar elegant axiomatic justification as Von Neumann and Morgenstern (1944) proposed for the ranking of lotteries. However, while in the risk context the cardinal utility function $u(y)$ represents the preferences of an agent over the bundle at each state of nature, the function $u(y)$ has a different meaning in the income distribution context. It captures the preferences of a social planner who is concerned with the ranking of incomes across individuals/households. As later clarified by Tony, there is nothing inherently utilitarian in this formulation (Atkinson, 1983a, 5).

The parallel with the theory of choice under risk inspired Tony to introduce the concept of the equally distributed equivalent income, $y_{e}$. This was an alternative representation of the standard additive social welfare function for a given distribution of income $F$ with mean $\mu: y_{e}=$ $u^{-1}\left(\int u(y) d F(y)\right)$ is an order preserving transformation of $W=\int u(y) d F(y)$. Yet, by replacing Dalton's proposal $\left[1-\left(\int u(y) d F(y) / u(\mu)\right)\right]$ with $\left(1-y_{e} / \mu\right)$, Tony ensured that his inequality measure is invariant to positive linear transformations of the function $u(y)$. Moreover, requiring that the measures of inequality be unchanged when rescaling the incomes of all individuals - a parallel condition to constant relative risk aversion - Tony noted that $u(y)$ has to be the power function $u(y)=(1-\theta)^{-1} y^{1-\theta}$ with parameter $\theta$ that can be interpreted as the degree of inequality aversion.

Another significant contribution of Atkinson (1970) was the proof of the equivalence between second-degree stochastic dominance and second-degree inverse stochastic dominance. Since the latter condition is equivalent, in the case of equal means, to preferring the upper of two nonintersecting Lorenz curves, Tony had shown that first-degree Lorenz dominance requires concavity 
of the function $u(y)$. Moreover, Tony demonstrated that the upper of two non-intersecting Lorenz curves can be obtained from the lower Lorenz curve by a sequence of Pigou-Dalton transfers, that is income transfers from richer to poorer individuals, provided that their ranks in the income distribution are unchanged. Together, this means that he had provided a normative justification for using the Atkinson measures of inequality for parameters that imposed a strictly concave functional form, i.e. $\theta>0$. Although Atkinson (1970) mainly dealt with inequality measures that are defined on the set of distribution functions, it should be noted that this paper also provided essential new insights on the Gini coefficient which is defined on the set of Lorenz curves. In this paper it was also demonstrated that the Gini is particularly sensitive to transfers of income that take place in the central part of the typical income distribution. While this property is universally acknowledged today, the origin of this result appears to have been overlooked. Note that Tony's evaluation of the transfer sensitivity of the Gini coefficient anticipates Kolm's (1976) principle of diminishing transfers and the recent focus on specific segments of the income distribution. On these aspects, see also Tony's 1973 paper later published as Atkinson (2008b).

Atkinson (1970) has had a huge impact on subsequent theoretical and empirical analysis of the distribution of income and wealth. Its influence is illustrated by its nearly 7,000 citations by Spring 2017, according to Google Scholar. It has greatly stimulated and still stimulates the development of this field as well as that of related research areas, such as the measurement of poverty and multidimensional deprivation and inequality.

\section{Multidimensional measurement of inequality and poverty, by François Bourguignon}

Measuring inequality when there are various dimensions in well-being that cannot be summarised into a commonly accepted single scalar is an issue that was first formally tackled by Tony in a paper on economic mobility (Atkinson, 1981a). In that paper, the social welfare function used in his iconic 1970 paper to evaluate a distribution of income was transformed into a function defined on the joint distribution of income in two periods $\left(y_{1}, y_{2}\right): W=$

$\int_{0}^{a_{1}} \int_{0}^{a_{2}} U\left(y_{1}, y_{2}\right) \cdot f\left(y_{1}, y_{2}\right) d y_{2} d y_{1}$, where $f(+)$ is the density of the joint distribution of the two incomes, $a_{1}$ and $a_{2}$ upper bounds for each one of them, and $U\left({ }_{+}\right)$the social valuation of individual welfare over periods 1 and 2 .

The generalization of the concept of dominance in Atkinson (1970) led him to define social welfare dominance of a distribution $f(+)$ over distribution $f^{*}(+)$ by the property that the social welfare associated to the former is greater than that associated to the latter for all functions $U\left({ }_{+}\right)$belonging to some general functional class. When this class includes all functions that are increasing and concave in their two arguments and the cross-derivative of which is negative, this criteria was shown equivalent to saying that distribution $f^{*}\left({ }^{*}\right)$ is obtained from distribution $f\left({ }^{*}\right)$ by a sequence of "diagonalising switches" - that is changes that leave the marginal distributions unchanged but increase the correlation between the two arguments.

We took a further step in Atkinson and Bourguignon (1982) where we considered a more general case in terms of the nature of the various arguments of $U(+)$ and different classes of $U(+)$ functions. We were able to generalize well-known second-order stochastic dominance results in one dimension to the bivariate case and apply them to social welfare dominance. We obtained various criteria, which essentially relied on the difference in the primitive of the cumulative distribution function of the joint distributions being compared on distinct domains of the $\left(y_{1}, y_{2}\right)$ space. As in the one dimensional case, these criteria could be expressed in terms of incomplete means and incomplete covariances of the two variables over different subspaces.

An interesting particular case of the preceding dominance criteria occurs when the marginal distribution of one of the two variables is the same in the two distributions being compared. This case is particularly interesting when one of the two variables is income and the other some fixed characteristic of the income recipient. In such a framework, it is thus possible to examine whether 
income redistribution improves social welfare when differences in the non-income characteristics of income recipients, e.g. their "needs", are taken into account. This was done in Atkinson and Bourguignon (1987), a draft version of which had been circulated in 1984, in which we derived an interesting generalization of Lorenz dominance, known to be equivalent to social welfare dominance in the one dimension case. It consisted of comparing the Lorenz curves of the income distribution before and after redistribution for all individuals above some level of needs, sequentially from the highest needs and in a decreasing order along the need axis.

Sequential Lorenz dominance concept is useful because we can then avoid making strong assumptions about the way the social evaluation of individual welfare depends jointly on income and fixed characteristics, like family size and composition, geographical location or health status. It is sufficient to order people in terms of their needs (based on their non-income characteristics). This also allows us to free the analysis of income inequality in terms of Lorenz dominance from the implicit assumption of identical income recipients in the non-income space. Jenkins and Lambert (1993) extended this analysis to the case where the marginal distribution of "needs" differ between the two distributions being compared.

It seemed logical to extend this analysis of income inequality when needs differ to the measurement of poverty. This was suggested in Atkinson (1987) where Tony discussed the application of dominance concepts to the comparison of poverty in two income distributions, dominance being defined in terms of all poverty intensity functions increasing and convex with respect to the poverty deficit, i.e. the gap between a poor person's income and the poverty line. (Foster and Shorrocks, 1988, also explored "poverty orderings", in a paper whose initial version goes back to 1984.) Tony provided a practical application later in a study of the social welfare impact of child benefits (Atkinson, 1992a).

Another source of multidimensionality in poverty measurement is when poverty is evaluated through deprivations of various sorts rather than monetary income. Some people may be deprived in one or several dimensions among those being observed - e.g. nutrition, housing, access to health care or quality education for children - whereas others may be deprived in more or less dimensions, and most importantly in different dimensions. Counting the number of deprivations should thus inform on who is poor and with what intensity. Very much under the influence of the Alkire and Foster (2011), the counting approach to multidimensional poverty measurement has gained a great deal of credit in the profession. Practically, poor people are those who are deprived in a number of dimensions greater than an arbitrary cut-off number, $c$, that depends, of course, on the total number of dimensions being considered. As in the one-dimensional case, it is then possible to define poverty intensity as some mean distance to poverty cut-off levels lines in the dimensions where a person is deprived.

This counting approach to poverty differs substantially from the social welfare approach that has been dominant in the inequality measurement literature, especially in Tony's work. Atkinson (2003) provided a formal link between the two approaches. In a nutshell, the counting approach may be seen as equivalent to restricting the social evaluation of individual welfare, $U\left({ }^{+}\right)$in the previous function for $W$, to $U\left(y_{1}, y_{2}\right)=-u\left[b_{1} I\left(y_{1} \leq z_{1}\right)+b_{2}\left[I\left(y_{2}, z_{2}\right)\right]\right]$, where $I(+)$ is the indicator function taking the value 1 if the condition in bracket is satisfied and 0 otherwise, $z_{1}$ and $z_{2}$ the poverty cutoff in each dimension, $b_{1}$ and $b_{2}$ the weight given to each dimension and $u(+)$ an increasing function that stands for the social cost of individual poverty - hence the opposite of social welfare. When $b_{1}$ and $b_{2}$ are equal to unity, the sum in square bracket is the deprivation count.

The preceding expression generalizes easily to any number of deprivations. A particular measure of poverty based on the deprivation count is associated to a particular function $u(+)$. For instance, it is common to define poor people as being deprived in more than $c$ dimensions with $c>0$. $u(+)$ would thus be a step function going from 0 to 1 when its argument gets greater or equal to $c$. A multidimensional poverty indicator may then be defined based on a combination of poverty deficits, i.e. the $z_{i}-y_{i}$ gaps, as in Alkire and Foster (2011). Tony's dominance approach avoids making such 
specific assumptions when comparing two distributions of welfare determinants. An analysis of the multidimensional poverty dominance criteria defined by the previous expressions for particular classes of functions $u(+)$ is provided by Aaberge and Brandolini (2015), which also gives an exhaustive summary of the multidimensional inequality measurement.

This in-depth analysis of the relationship between poverty measurement based on social welfare or on deprivation counting is a perfect example of Tony's research method, which consists of systematically going back to basic social welfare concepts. Retrospectively, the number of results, properties and analytical tools he was able to derive from such an approach is impressive. All these results, whether uni- or multidimensional, have become canonical in distributional analysis and will be referred to as such for a very long time.

\section{Intergenerational income mobility, by Markus Jäntti}

During a remarkably productive period from the late 1970s to the early 1980s, Tony wrote, on his own and with co-authors, a series of reports which contain key methodological insights for the study of intergenerational income mobility. Moreover, in the absence of suitable data, Tony and his collaborators carefully and judiciously constructed their own. Thanks to this work, the intellectual roadmap with which to explore intergenerational links was largely in place in the early 1980s.

Data. Atkinson, Maynard and Trinder (1983a) note that collecting contemporaneous data from both parents and children around the same calendar date leads to pairs of observations observed at very different points in their life cycles, leading to serious biases. To obtain information that pertains to roughly similar stages in the life cycle for both parents and children, there are three main approaches: (1) longitudinal data collected on a prospective basis on parents and at the same stages in the lifecycle; (2) retrospective data with parental outcomes collected from current respondents; and (3) record linkage, with data collected from offspring to respondents of an earlier source that have been traced. Option (1) is challenging as it takes decades before results are available, while retrospective studies (2) are not likely to provide accurate information to income questions. Atkinson, Maynard and Trinder (1983a) opted for record linkage (3). The most promising candidate for this was a study conducted in 1950 of poverty in the city of York by Seebohm Rowntree (Rowntree and Lavers, 1951). What followed was time-consuming detective work to trace and interview the children of the respondents of the original survey and to link their data with that of their parents. See Atkinson, Maynard and Trinder (1983a, 1983b) for details. The result was one of the only datasets (at the time) with information for two generations about individual earnings and household income and for a relatively large sample.

Estimation problems. Intergenerational income mobility (or persistence) is usually summarised in two ways. Persistence is commonly studied by a simple Galtonian regression (Galton, 1886) of the natural logarithm of offspring income on that of the parent. The slope coefficient $\beta$ is the measure of intergenerational persistence. If generational income variances are equal, that is the economy is in "steady-state", $\beta$ equals the intergenerational correlation $\rho$; in that case $\beta(=\rho)$ can also be measured by the square root of $R^{2}, R$. An alternative approach is to examine the transition matrix, which is directly informative of the extent of not only persistence (e.g. the fraction on the main matrix diagonal) and but also the patterns of mobility (e.g. whether there is symmetry in upward and downward mobility as shown by the off-diagonal entries).

Atkinson (1981b) addresses many measurement issues in pioneering fashion. That parental income data in Rowntree's sample excluded upper-income families need not lead to a problem for estimating $\beta$, but $R$ is no longer equal to $\beta$. For transition matrices, truncation of the top fourth of the parental distribution means that in a $4 \times 4$ transition matrix, the bottom row is missing. However, Tony shows that a quartile-group based transition matrix is bi-stochastic, so that the missing information can be deduced. 
Atkinson (1981b) also considers two further issues concerning measurement error. First, responses to survey questions on earnings may generate inaccurate answers. For many of the Rowntree parents, earnings data stemmed from more accurate employers' reports, reducing the problem. The implied $\beta$ for plausible but assumed relative error variances can be backed out, but estimation could also rely on the subset of data with employer-provided father's earnings. Tony also points out that deviations of current-period from permanent income can be handled as measurement errors, and he works out the implications from estimates of relative transitory variances. Tony's result about attenuation bias in $\beta$ is essentially the one later rediscovered and popularised by Solon (1989, 1992). Measurement errors also in offspring income leads the transition matrix to overstate mobility. Moreover, in a separate paper, Atkinson (1983b) also raises the potentially serious issue of biases from measuring offspring and parental incomes at different lifecycle stages, a topic taken forward subsequently by others (e.g. Jenkins, 1987; Grawe 2006; Haider and Solon, 2006; Böhlmark and Lindquist, 2006).

Intergenerational welfare analysis. Often concerned with the welfare-economic implications of mobility, Atkinson (1981b) uses the intergenerational regression to construct a (log variancebased) social welfare function that depends on consumption in childhood (equalling some fraction of parental income) and adulthood (depending on own income) and asks how $\beta$ affects aggregate welfare. Intergenerational persistence increases the variance of welfare (and thus reduces social welfare) by a considerable amount.

Atkinson and Bourguignon (1982) ask in which of two intergenerational distributions welfare is higher. The key to answering the question is a utility function, $U\left(Y_{P}, Y_{O}\right)$, which has social welfare increasing in both parental $\left(Y_{P}\right)$ and offspring $\left(Y_{O}\right)$ income. The effect of mobility on social welfare depends on the cross-partial derivative of $U, U_{12}$; mobility increases social welfare only if it is negative. Empirically, this was implemented by examining the cumulated difference in two estimated transition matrices. Starting from the lowest classes (top-left corner), one cumulates the differences in mobility; if all differences are negative, the first distribution has higher welfare than the second.

Empirical results. Atkinson and his co-authors estimate intergenerational $\beta$ s for many parentoffspring samples and different definitions of individual earnings and income. Several interesting observations arise from inspection of these estimates. For instance, the $\beta$ s for sons and fathers earnings (hourly and weekly) span a range of values $(0.316-0.428)$ which are consistent with later estimates for the UK. It is worth noting that the work includes also an intergenerational $\beta$ for household disposable income for all persons, an outcome variable which remains only rarely studied. In addition, Atkinson, Trinder and Maynard (1978) find that $\beta$ s for sons-in-law and fathers are considerably higher than $\beta$ s for sons and fathers, an issue which has received some attention in recent literature (Chadwick and Solon, 2002).

\section{International Inequality Comparisons and LIS, by Tim Smeeding and Janet Gornick}

The early years. I (Tim) met Tony in 1985 when Tony attended the first Luxembourg Income Study (LIS) conference - the one at which LIS' founders held their breath, because, depending on what Tony and others said, the project would grow or die. Tony quickly became a strong supporter of LIS, helping the project in countless ways. One of Tony's earliest contributions was to write the introduction to the first LIS book; he closed that by stating his enthusiasm for LIS and its promise, and pledging his support (Atkinson, 1990b). Of course, he followed through in great fashion.

In 1993, when the OECD asked me to write a report on income distribution in OECD countries using the LIS data, I knew instantly that the collaborator I most wanted was Tony; fortunately, Tony jumped at the chance. Together with Lee Rainwater, I and Tony worked for a year, learning an immense amount from one another. As one example, Tony wrote Chapter 2 in that volume, which linked the income distribution microdata literature to macroeconomic concepts and to national accounts. That chapter remains the clearest and most useful explanation of those linkages; 
and, today, those micro-macro linkages are all the rage. That historic volume (Atkinson, Rainwater and Smeeding, 1995) established LIS as the "gold standard" for cross-national comparisons of income inequality, and served as the effective beginning of OECD's income distribution data project.

Tony was, for years, a generous source of advice and inspiration to LIS - and to many other projects and colleagues as well; it is hard to overestimate his impact. When the Society for the Study of Economic Inequality (ECINEQ) was founded in 2005, the first Scientific Council and Executive Committee had an easy choice for the society's inaugural President; of course, it was Tony, who immediately established the credibility and stature of ECINEQ. Tony would later help to launch and lead the World Top Incomes Database, and its successor, the World Wealth and Income Database; several sets of income inequality estimates have emerged from those excellent databases as well (Alvaredo et al., 2017).

The later years. After enhancing the content of LIS' work for more than 25 years, Tony assumed a different and equally valuable role. He served as LIS' Board President, for five years to the day, from 1 January 2012 until the day of his death.

When Tony agreed to become LIS' President, I (Janet, then LIS Director) and the LIS team were grateful. We knew that we were fortunate to have such an esteemed scholar at the helm. What we did not know (but, in retrospect, should have) was that he would serve as a deeply involved, entirely hands-on, active President - making himself available for counsel on countless decisions, large and small.

Throughout his tenure, we consulted Tony about LIS' overall strategies and priorities. We sought his advice on data and measurement concerns, on LIS' aggregate statistics, on the challenges of microdata dissemination. We asked for his ideas on fundraising, on budgeting, on resource allocation, on personnel decisions, on European data politics. We requested that he serve on search committees and join LIS at public events. We called upon him to persuade statistical offices to share their data. We invited him to visit the US Office of LIS, so that he could help strategize about LIS' work on the American side of the Atlantic.

Tony always engaged with the LIS team as if he had all the time in the world - which, of course, he did not - and as if no question were too small. His advice meant the world to us. Whatever the issue, he would bring his decades of experience to bear as he raised key questions for discussion. What would lead to the highest quality harmonized data? How could we balance data access with data protection? What would most enhance our users' research? What would work best for our staff? What would be most equitable for all involved? Did we have the bandwidth?

When Tony held a strong view, he would convey it directly, providing his reasoning. (And when Tony held a strong view, as his many fans know, he was not readily dislodged from it.) In the end, Tony gave LIS more time and wisdom than we could have ever hoped for or imagined. And he did it with grace, and elegance, and with his quiet wry wit. He also served as a welcome cheerleader, sending celebratory emails about LIS' achievements. He weighed in when the world beyond our walls bewildered us all; recent political and policy developments in the UK and elsewhere worried him deeply.

In recent years, as Tony's health faltered, he generously thought about LIS' future. He spoke with the LIS leadership about how LIS could best secure its future. Tony was gratified by his two final accomplishments at LIS. First, in 2014, I and the LIS leadership concluded that LIS had grown too large for a single Director. Tony oversaw a reorganisation; LIS decided to search for a new senior scholar to direct the Luxembourg LIS Office. (I would shift to directing the US LIS Office). Tony played a central role designing this position and assembling a stellar search committee. He was immensely pleased and relieved when Daniele Checchi accepted the new position, one that he assumed on 1 September 2016. Second, in July 2016, Tony told the LIS team that the time had come: we had to begin the process of bringing in a new President. He asked us, with characteristic modesty, if we wanted his view as to who might be his ideal successor; of course, we did. He had a single 
scholar in mind - his long-time colleague François Bourguignon - who agreed, in honour of Tony, to step into Tony's enormous shoes.

Scores of Tony's colleagues and students have engaged with LIS, as data users, researchers, co-authors, supporters, and friends. When Angus Deaton learned of Tony's loss, early on 1 January 2017, he responded: “A voice we cannot bear to lose”. That is true. Tony will never be replaced. We, and the entire LIS community, will miss him more than words can convey.

\section{Long-run evolution of inequality, by Thomas Piketty}

One of Tony's most important and profound scientific contributions has to do with the study of the long-run evolution of inequality. In a way, together with Simon Kuznets, Tony almost singlehandedly originated a new discipline within the social sciences and political economy: the study of the historical trends in the distribution of income and wealth. Of course, the question of long-run trends in distribution already lay at the heart of nineteenth-century political economy, particularly in the work of Thomas Malthus, David Ricardo, and Karl Marx, but these writers could draw only upon limited data, and were frequently obliged to limit themselves to purely theoretical speculation. It was not until the second half of the twentieth century that the research of Kuznets and Atkinson on the distribution of income and wealth could actually be based on historical sources.

In his 1953 masterwork, Kuznets combined the first systematic records of American national income accounts (records that he himself had helped to create) and the data produced by the federal income tax (established in 1913, in the aftermath of a prolonged political battle), to establish the very first historical account of year-by-year income distribution. Kuznets found a large decline in the share of national income going to the top 10\% over the 1913-1948 period (from almost 50\% to little more than 30\%) and a corresponding rise in the share going to the bottom $90 \%$. These findings led the formulation of the optimistic theory of the Kuznets curve, according to which income inequality naturally tends to decline in advanced stages of development. Although this theory has by now been largely abandoned, the methodological advances that led to these series are still very significant.

In 1978, in Distribution of Personal Wealth in Britain, a fundamental book co-written with Alan Harrison, Atkinson outstripped and overtook Kuznets: he made systematic use of British probate records from the 1910s to the 1970s to analyze in magisterial fashion the extent to which different economic, social, and political forces can help us understand the developments observed in the distribution of wealth, a distribution that was particularly under scrutiny during this period of exceptional turbulence. Tony is able to document the spectacular fall in top wealth shares, using different sources and methods (inheritance tax returns via estate multiplier method, and income tax returns via income capitalization method).

Compared to Kuznets' book, which was mostly concerned with the construction of the statistical database, Atkinson's book goes a step further, in the sense that it better articulates the data collection with the historical and theoretical analysis. Instead of formulating excessively optimistic and universal laws about inequality dynamics (à la Kuznets), Tony explores the different structural forces and mechanisms that can give rise to different steady-state levels of wealth inequality (in particular the gap between rates of return and growth rates and the progressivity of the tax system). In this respect, Tony's work has taught us how a meticulous and sober treatment of data should be used to lead to sharp conclusions and innovative policy action.

All subsequent work on historic trends in income and wealth inequality to a certain extent follow in the wake of Kuznets's and Atkinson's groundbreaking studies. In particular, the entire WID.world project can be viewed as a mere continuation of the Atkinson-Kuznets agenda. Tony was the driving force behind the two multi-country volume that we edited together (Atkinson and Piketty, eds., 2007, 2010) and the continuous expansion of the project (see Atkinson, Piketty and Saez, 2011, and Alvaredo, Atkinson, Piketty and Saez, 2013, for surveys of this literature). A few weeks before he died, Tony was contributing to the DINA (Distributional National Accounts) Guidelines - an 
ambitious attempt to combine national accounts, household surveys and fiscal sources in a more systematic and consistent manner than what was done before. This ongoing research programme follows directly from the Atkinson-Kuznets agenda. It shall continue.

\section{Global poverty, by Francisco H. G. Ferreira}

Tony's contributions to the measurement and analysis of poverty are multiple, longstanding, and many are well-known. They date back to the first book he ever published, in 1969, on poverty and social security reform in the UK (Atkinson, 1969a), and include his 1985 Walras-Bowley Lecture to the Fifth World Congress of the Econometric Society (Atkinson, 1987). That paper was the first to apply stochastic dominance criteria as tools for assessing the robustness of poverty comparisons, with respect to the choice of both the poverty line and the poverty index. As seen, Tony was also present at the origins of multidimensional poverty measurement, through his work with Bourguignon on applying multivariate stochastic dominance results to the measurement of multidimensional poverty and inequality.

But, to the best of my knowledge, Tony's earliest venture into the measurement of global poverty - poverty in the world as a whole, as distinct both from poverty within a country and from global inequality - came in another joint paper with Bourguignon: Atkinson and Bourguignon (2000b) asked who should be identified as "the world's poor", given the inherent diversity in what "poverty" means across societies with radically different levels of material well-being. They argued that the positive association between national poverty lines and average consumption levels across countries - which was empirically documented for a sample of 33 nations in 1985 by Ravallion et al. (1991) - could be seen as consistent with Amartya Sen's idea that a poverty standard might be absolute in the space of capabilities but vary in the space of commodities, depending on the societal context (Sen, 1983). Perhaps poverty lines were higher in richer countries because higher incomes were required for people to achieve the same functionings: e.g. finding a job might require only a bicycle in a poorer country, but might be impossible without internet access in a richer one.

With that in mind, and clearly motivated by the observed empirical association between national poverty lines and average consumption, Atkinson and Bourguignon (2000b) proposed a novel method for the identification of the world's poor, which combined elements of the traditional absolute approach followed in most poor countries, with the relative approach followed in many rich countries. Individuals would be classified as poor if their per capita household consumption (or income) was less than a poverty threshold set as a (non-decreasing) function of a country's average living standard, $z\left(\mu_{c}\right)$. However, because up until some positive income level, the capability associated with bare survival would take precedent, they proposed that $z\left(\mu_{c}\right)=\max \left(z^{*}, k \mu_{c}\right)$. In other words, the "global poverty line" would be a fixed monetary amount, $z^{*}$, for countries poorer than a certain income level $\left(\mu_{c}=z * / k\right)$. For richer countries the poverty line would be a relative one, and rise at rate $k$ with the country's average income. Over a decade later, the Atkinson and Bourguignon (2000b) proposal was picked up and slightly modified by Ravallion and Chen (2011, 2013), and by Jolliffe and Prydz (2017). The latter will provide the basis for one of the new complementary measures of global poverty that the World Bank intends to start reporting in 2018.

Tony returned to the measurement of global poverty in June 2015, when he was asked by Kaushik Basu, then Chief Economist at the World Bank, to lead a global commission of experts set up to advise the Bank on how to monitor global poverty in the future. The background to the convening of this Commission was the publication by the International Comparison Project (World Bank, 2015) of the 2011 Purchasing Power Parity exchange rates (PPPs). Whereas the 2005 PPPs had previously led to downward revisions in our assessment of real well-being in poor countries (e.g. Chen and Ravallion, 2010), the 2011 PPPs suggested that the developing world was actually richer than implied by the 2005 conversion factors (e.g. Ferreira et al., 2016). PPP exchange rates designed to account for the fact that non-tradable goods and services tend to be cheaper in poorer 
countries - are an essential ingredient into global poverty measurement: they provide the best-known means of comparing real standards of living across countries in a meaningful manner. Yet, the apparent instability in the comparisons across waves of the price surveys and index computations might cast doubt on the validity of the entire exercise. Basu and his team at the World Bank felt external guidance was needed, and sought to convene a group of knowledgeable experts to advise them. Tony was the natural Chair for this Commission and, though he was already struggling with his terminal illness, he graciously agreed to lead it.

The report of the Atkinson Commission (Atkinson, 2017) was published in late 2016, a few months before Tony's death. Although he had consulted widely - both within and beyond the 24member commission - Tony wrote the report single-handedly. It contains twenty-one recommendations, broadly organized into two themes: (i) how can we better monitor progress towards Sustainable Development Goal 1.1; and (ii) what complementary poverty indicators should the World Bank also track, in addition to the proportion of people living under \$1.90/day. The 232page report is characteristically rich and thoughtful, and it is impossible to do it justice here. Rather than attempting a comprehensive summary, we simply highlight two features of this volume that evoke Tony's broader legacy, and which will be very important for the World Bank's future work on monitoring global poverty.

The first is a thoroughgoing attention to data quality. Tony did address the immediate question put to the Commission regarding the use of PPPs to monitor progress towards the goal of eradicating extreme poverty by 2030. The Commission recommended that the 2011 PPP conversion factors be used until 2030, with updates in the (local currency values of) the International Poverty Line reflecting only changes in national consumer prices. But, once he started digging into the different data sources that were involved in the estimation of the global poverty headcount, he went much further. He recommended that greater care be taken to avoid possibly "missing groups" of poor people, because of survey under-representation or non-coverage, as well as inaccuracies in population censuses. He suggested setting up a joint statistical working group to examine the international comparability of consumption (and income) statistics; and drew attention to the importance of improving the quality of domestic consumer price indices. Finally, he confronted the "elephant in the room" by noting that much of the uncertainty around global poverty estimates arises from non-sampling errors, and urged producers to follow a 'total error' approach in communicating the existence of that uncertainty.

The second feature reflects Tony's unrelenting intellectual openness. In a debate where participants often adopted inflexible positions on what was the "correct" approach to measuring global poverty, Tony suggested that the Bank should report an eclectic variety of indicators, drawing from a range of different methodological perspectives, as complements to its core extreme consumption poverty measure. (Tony's perspective on the use of multiple indicators for tracking global poverty was also shaped by his earlier work on social indicators for the EU; see, e.g. Marlier and Atkinson, 2010). These included multidimensional indicators, subjective poverty measures, and societal (or "weakly relative") indices, drawing on the Atkinson and Bourguignon (2000b) approach discussed above. Although it is rare, such broad-mindedness should not surprise us. Already in the introduction to Atkinson $(1987,750)$, Tony noted that “...there is likely to be a diversity of judgments affecting all aspects of measuring poverty and [...] we should recognize this explicitly in the procedures we adopt”.

\section{Public economics 1, by Joseph Stiglitz}

Tony’s most recent book (Atkinson, 2015) provides a brilliant compendium of ideas on how to attack inequality, including several that were bold and innovative. Most of these are ideas about what the government could do. Tony believed that society's major problems could only be addressed through collective action, through the State. And as in all the other areas in which he was engaged, 
he believed that research would help us understand better what the government could and should do - and how it could do what it should do better. Reasoned discourse based on science, combining deep theoretical work with evidence, obtained through careful and meticulous research, was the only way to achieve progress and create a better society. In Cambridge, at the time he was studying there (in Churchill College, under Frank Hahn), this was one of the two strong traditions - led at the time he was there by James Meade, with antecedents in Arthur C. Pigou. This tradition, so clearly linked with the Enlightenment in its world view, is all the more appreciated today as these values and perspectives have come under assault.

I worked with Tony on much of his early work in the field of public economics. Tony and I became good friends during my year as a Fulbright scholar at Cambridge in 1965-66, a little more than a half century ago. Hahn had asked me to supervise Tony - he was my first student ever. But almost immediately, we became collaborators and co-authors, working closely together for fifteen years, until I left England in 1979. Tony, his wife Judith, and I became close friends, spending time together on both sides of the Atlantic.

Tony's work in public economics changed forever the field of public economics, so much so that it is hard even to recognize the subject as it previously existed. Though the public sector represented some one third of GDP in most advanced countries, and though it was recognized that government actions - including its rules and regulations, the taxes it imposed and the public goods it provided - were vital in determining the behaviour of the private sector, there was no systematic and comprehensive analysis of the economics of the public sector. The closest field to that of modern public economics was called public finance, and it had been traditionally a far more institutional field. The standard text before Atkinson and Stiglitz (1980) was The Theory of Public Finance: A Study in Public Economy, by Richard A. Musgrave (1959), described by another great contributor to the field, James Buchanan, as “the first English-language treatise in the field” (1960, 234). As Tony was beginning his study of economics, mathematics was becoming the language of economics. There had been, of course, a number of isolated studies analyzing various aspects of the subject using, in varying degrees, modern techniques - Harberger’s (1962) general equilibrium analysis of the corporate income tax or Tiebout's (1956) analysis of competition among local communities. While we were in Cambridge, James Mirrlees working with Peter Diamond at MIT was opening up the formal analysis of normative public economics, with their work on optimal taxation (1971a, 1971b), building on work done years earlier by Frank Ramsey (1927). On the expenditure side, there was Samuelson's (1954) formalization of the pure theory of public goods, as well as nascent work in cost-benefit analysis. Arrow and Debreu's proof of the first and second welfare theorems provided the analytic background to the development of the market failures approach to public action. And of course, in the analysis of social choice, the work of Arrow (1951) was brilliant, but it was not obvious to see how to incorporate this into analyses of either how the good should or did behave.

We saw as our task bringing together all these strands (and others, often less formal, such as "public choice" theory as it being developed then by Olson, Buchanan, Tullock, and Downs and their colleagues) into a comprehensive general equilibrium approach, to think through systematically how public policy affects households, firms, and the functioning of markets, and on the basis of that description, to formulate a positive analysis of the full consequences of different government actions and a normative analysis of what it should do. We saw that task as beyond what we could do in just a few years; but we believed that outlining the approach would motivate others to fill in the gaps.

Thus, we modestly called our book Lectures on Public Economics, to highlight that we had not yet achieved our ambition of creating a Theory of the Public Sector. Besides, as our work progressed, we became increasingly aware of the importance of institutional constraints, carefully considered in full detail - what, for instance were the feasible sets of taxes from among which the government had to make a choice. Some of these were the result of informational constraints - imperfect information meant that there could be credit rationing even in an otherwise well-functioning market economy. 
These constraints, even those arising out of economics rather than politics, could vary from country to country, e.g. between developed and less developed countries.

Two of the central theoretical contributions (incorporated into our book - and which helped motivate us to write the book) focused on the design of tax structures (Atkinson and Stiglitz, 1972, 1976). Ramsey's truly brilliant work on optimal taxation - on how to levy a set of taxes so as to minimize the "deadweight loss" generated by the tax - had carried a simple message: tax goods which had a lower elasticity of demand at a higher rate. Tony and I found this deeply disturbing, since among the goods with a low elasticity were necessities of life. Ramsey taxes were regressive. At the time, some policy economists were taking up Ramsey's analysis, and this posed a threat.

What Ramsey had left out was inequality. He had assumed, in effect, that all individuals were the same. But if that were the case, one should simply impose a lump sum tax. And it was hard to see how, in that mythical world, there would be any objection to doing so. We lived in a world in which there were differences, but they were sufficiently difficult to observe/verify that one could not impose differentiated lump sum taxes. On the other hand, it was clear that a uniform lump sum tax was regressive and unacceptable. In our 1972 paper, we showed that the optimal taxes taking into account distributional concerns looked markedly different from Ramsey taxes, and we succeeded in getting a simple formula incorporating distributional concerns.

We still felt unsatisfied. Ideally, one would impose a higher lump sum tax on those with higher capabilities. If one could identify those capabilities, then financing public goods in a "fair way”, it would be possible to maximize social welfare, with say a Benthamite social welfare function, without any distortion. But how to raise revenues when one cannot observe abilities was the problem that Mirrlees had solved in his work on the optimal income tax. The question was, if one had an optimal income tax, was there any need for indirect (commodity) taxation at all? Could it be that if one had an optimal income tax (or even a reasonably well designed income tax), the optimal commodity tax was just 0 ? The answer was strikingly simple: if there was separability between consumption of goods, on the one hand, and labour on the other, there should be no commodity taxes. In the absence of separability, one should tax or subsidize different commodities, but those taxes/subsidies had nothing to do with Ramsey taxation (and the price elasticities that he had identified as critical).

Our work had begun by trying to debunk the use of a theory in an inappropriate way (the use of regressive "optimal” Ramsey taxes) but it unfortunately led to another graver problem: a direct implication of our analysis was that there should be no taxes on interest, which amounted to taxation of consumption in different periods at different rates. Not taxing interest was obviously regressive. Tony and I would spend much time explaining the assumptions of our model, and why it was inappropriate to use it to reach that conclusion.

Tony was the master of simple models. These models are sometimes call "toy models." But Tony was aware of both the strengths and weaknesses of these models. His work in public economics was deeply rooted in the real world, and he understood the gross simplifications that were made in the name of analytic tractability. He understood too the dangers with the misuse of these models. Economic policy was too important to be toyed with. Basing economic advice on a toy model was like doing an experiment with humans. Lives and well-being were at stake.

Lectures on Public Economics helped define the field for a generation. An enormous literature was spawned, much of it empirical. For years, we discussed doing a new edition, incorporating these advances. In the end, in 2014, as Princeton University decided to re-issue the Lectures, we decided to write a preface, outlining the major changes that we believe we would have incorporated into our analysis, such as those represented by the advances in behavioural economics, and how they might have changed the analysis and conclusions. Our collaboration on this project was as exciting and pleasurable as that of our first projects, and it recalled the many days we had spent together. Our work had shown how "two heads are better than one.” By the end, it was almost impossible to separate out our individual contributions. Each idea of one built on another idea of the 
other. It was perhaps not surprising that we saw the world through such similar perspectives - even as we discussed questions that we had not delved into in our earlier research.

We launched the book together in Trento in its annual Festival of Economics (where economic books and ideas are discussed and debated among thousands gathered together in that small city) in June 2015, and the event brought together for me so many aspects of Tony's life: His belief that economic research and analysis could lay the foundations of better public policy; that achieving better policy required civic engagement, with reasoned discourse through democratic processes. Throughout, there was a commitment to making the world a better place.

I have been asked to write about his intellectual contributions in public economics; but I must add a word about Tony himself, to say how much our friendship and collaboration meant to me, how I admired and respected him in every aspect of how he led his life and treated others, the multiple roles he played in public policy, how he never lost or forgot the link between economic analysis and public policy - cautious and precise about what economic science had to say. He was an exemplar of a scholar in public life. He was of a rare breed. He will be deeply missed.

\section{Public economics 2, by Nicholas Stern}

For Tony, public economics was "interpreted widely to include all aspects of government policy of interest to academic, government and other economists”, as he explained in his editorial with Martin Feldstein, Leif Johansen and Joseph Stiglitz introducing the first issue of the Journal of Public Economics in April 1972. Tony was the key force behind and founding editor of the journal. He was, at 27 years old, a real leader and builder. He had been publishing and shaping the subject for several years.

For Tony, "questions of interest" were those of real importance to the well-being of people, particularly poor people. He saw public economics, and economics more generally, as a subject of great seriousness, where questions had to be posed and handled with conceptual care and using the best of theory and evidence available. Thus he asked, for example: what does poverty mean, how do we measure it and what can we do about it? That was the subject of his first book, Atkinson (1969a), and he asked similar questions on inequality in his last book (Atkinson, 2015). For Tony, throughout an extraordinarily productive publishing life of half a century, poverty and inequality were at the heart of his research and policy agenda.

Much of his intellectual contribution to the microeconomic aspects of public economics was in the noble tradition of Dupuit, Wicksell, Marshall, Pigou, Meade, Arrow and Samuelson. In that tradition he placed at centre stage the importance of thinking carefully about objectives and moral values. And in modelling the economy and formulating policy, market imperfections and constraints on information and taxation were centre stage.

He emphasized the importance of thinking in terms of general, rather than simply partial, equilibrium (an influence he attributed in part to his teachers at Churchill College, Cambridge, Frank Hahn and Jan Graaff). His Lectures on Public Economics (Atkinson and Stiglitz, 1980) became a standard text in which they developed and explained clearly (then) modern theories of optimal taxation of goods and income in imperfect economies, with constrained information and limited instruments.

Later in life, he came to see the assumptions of standard general equilibrium theory as much too narrow and placed great emphasis on understanding economics in terms of changing structures, institutions and behaviours. Over the last few years, we discussed together the importance of building a "dynamic public economics" where not only behaviours and institutions change, but also the pace of change matters. This is clearly of great importance in the economics of climate change where it is the integral of emissions over time which influences concentrations of greenhouse gases, which influences climate. Hence, delay is dangerous. We should think both about disequilibrium, 
about the causes of changes in behaviours and institutions, and how fast events occur and outcomes change.

One of Tony's great interests in public policy was in measurement and its relationship with the concepts and policies under discussion. Thus, for example, in thinking about living standards, poverty and income distribution, he was much concerned with the coverage of goods, services and activities in household surveys. So, too, equivalence scales for family structure in relation to assessing the welfare of families. Similarly, in looking at productivity change and policies to promote it, he would want to examine carefully the definitions of output and input used in the comparisons. Indeed, when I was briefly at the UK Treasury in the early 2000s, we asked him to examine the measurement of public sector output. He produced a very thoughtful, careful, important and influential report (Atkinson, 2005a). This showed how we could do much better in terms of informative statistics than measuring public output by input, the conventional approach. And we could and should avoid crude mistakes such as measuring the output of the fire services by fires attended. He always said he learned much on measurement and attention to detail with data from working with Richard Stone and Brian Reddaway in Cambridge in the 1960s.

Tony's concern with care over data was legendary. He was a pioneer in the examination and use of household data to measure poverty and the distributional impact of policies; but others in this article will be writing about these aspects of his work.

I had the great good fortune to collaborate with Tony over 50 years, our first article together (Atkinson and Stern, 1972) was published 45 years ago. I joined him as editor of the Journal of Public Economics a few years after its foundation and continued for nearly two decades until we handed over to the "next generation". With Mervyn King, we created in the early 1980s the ESRC research programme "Taxation, Incentives and the Distribution of Income”, which continued at the London School of Economics and Political Science for a dozen years, attempting to integrate the policy questions of the day, modern theory, and the use of household data sets.

Tony was a giant in our profession; someone who shaped decades of research. He led not only by applying his extraordinary intellectual talents but also by bringing deeply decent values to the core of the analysis of the big issues of our time. He was one of the finest and most inspiring human beings. Half a century of friendship and collaboration with Tony was one of the great gifts of my life.

\section{Welfare State, by John Hills}

Interleaved with Tony's writings on inequality and poverty was a lifelong concern with the welfare state, and in particular with social security systems. This ran from his first book (Atkinson, 1969a) to his last (Atkinson, 2015). At the LSE Tony established the Welfare State Programme (which later evolved into the Centre for Analysis of Social Exclusion) as a complement to the Taxation, Incentives and the Distribution of Income programme discussed by Stern above. In Tony's personal life, his concern with the welfare state ran from manning tables on the street to offer advice on benefit claims to discussions and influence at the highest levels of European decision-making.

Throughout his writing and analysis of the welfare state, as elsewhere, he emphasises again and again four features.

Design matters. How welfare states affect economic growth, for instance, is not just a matter of the share of social spending in GDP, but of how that spending is deployed (Atkinson, 1999). Nor are the aims against which they should be judged just about poverty relief, but also involve life-time income smoothing, insurance, redistribution according to relative needs, and relative gender positions (Atkinson, 1995c).

Details matter. For instance, rules on who is entitled to unemployment benefits and the conditions applied to their receipt, either in terms of previous social insurance contributions or of behaviour while claiming, mean that the economics of their potential effects are far more complex 
than those of a simple "payment while out of work" (Atkinson, 1992b). At the same time, often unnoticed changes to such rules have major effects on the effectiveness of social security systems such as the seventeen different kinds of reduction to the generosity of UK unemployment benefits he and John Micklewright identified in the 1980s over and above headline benefit rates (Atkinson, 1990c; Atkinson and Micklewright, 1991). In the 1960s, the "wage stop” limits on benefits related to past (low) earnings mattered. In the 2010s, "sanctions" and removal of benefits matter.

As a result, real-world systems and behaviours are often a very long way from those assumed in public debates. People may be entitled to particular benefits, but often fail to claim them, a key reason for the failures of means-tested systems to be as effective a response to poverty as proponents of "targeting” might assume (Atkinson, 1969a, 2015). Incentives are not just about making a free choice between working a certain number of hours or not working at all, but a whole series of other decisions about work intensity and commitment, retirement, and wider behaviour.

And as a corollary, data matter. If we are to understand the effectiveness of social security systems we need to know what incomes people actually receive, not what a table of benefit entitlements would suggest (Atkinson, 1989). If we are to understand the costs and distributional effects of reform to one part of the system, we need ways of analysing data that model the interactions with the other parts - one of the drivers behind his pioneering work on and use of microsimulation models.

Following from his insights in all four respects, his analysis of "what could be done" in different periods returns to the importance of universal child benefits and of adequate state retirement pensions alongside a continuing personal debate between the advantages of social insurance ("Back to Beveridge") approaches and of citizens' or basic incomes.

This all came together in his proposals for "social security for all” in his 2015 book. Tellingly, though, his proposals for social security are not where he starts, but come in the fifth chapter of his "proposals for action", and are the twelfth to fourteenth of his fifteen recommendations for reducing inequality. But beyond the other areas for action he concludes that, "The welfare state has in the past played a major role in reducing inequality. It is the primary vehicle by which our societies seek to ensure a minimum level of resources for all members. One reason for rising inequality in recent decades has been the scaling back of social protection at a time when needs are growing, not shrinking” (Atkinson, 2015, 205).

By implication, reversal - and more than reversal - of cuts to child benefits and pensions play a central part in his proposals and the packages modelled. Both could be seen as "basic incomes" for those below and above particular ages. But he presents two alternative routes for social security of those aged in between, one based on revived social insurance and one based on "participation incomes”, rather than citizens' incomes.

His reservations about the most straightforward forms of basic incomes can be seen in the conclusions of his first book: their uniformity in the face of people's varying needs; the effects of getting rid of the more complex - but more generous for some - existing benefits; the ambiguous effects on work incentives when the substantial taxes required to pay for them are allowed for; benefits for those on high incomes in the versions that couple them with flat taxes; and the smaller administrative savings than often claimed when introducing them in the real world (Atkinson, 1969a, 186-187).

Over the years, his ideas evolved, alongside investigation of variants of the basic incomes approach, such as partial basic incomes, supplemented by other benefits for particular needs (Atkinson, 1995a). By the time of his 2015 book one of the two variants of his package incorporated a "participation income", with a wide range of activities counted as "making a social contribution", so few would be excluded beyond the famous Malibu surfers. He rejected "citizenship" as the criterion for receipt as being simultaneously too extensive for political acceptability, but too narrow to be compatible with what he assumed were rights with continuing membership of the EU. But as an 
alternative to this he laid out detailed plans for a renewal of social insurance, taking account of the way the labour market has changed, both raising the level of benefits and extending their coverage.

His analysis and his concerns led to ambitious proposals for the welfare state, in the face of the challenges of the twenty-first century, such as population ageing. But he refused to be pessimistic, arguing that, "the solutions to these problems lie in our own hands" (Atkinson, 2015, 308).

If we choose to use them, our hands are all stronger as a result of his work.

\section{Tax-benefit microsimulation models, by Holly Sutherland}

Among his many contributions during his long and extraordinary career Tony was instrumental in establishing research communities and institutions that will endure. EUROMOD, the tax-benefit microsimulation model for the EU is one of these (Sutherland and Figari, 2013). It recently celebrated its $20^{\text {th }}$ birthday and is in the process of being adapted for use in middle- and lower-income countries in Latin America and Africa, among others, encouraged and inspired by Tony's global perspective. Tony not only provided the intellectual foundations for the use of taxbenefit microsimulation models in the rigorous and detailed analysis of the distributional and other effects of policies and potential policy reforms but was also actively involved in their use. This included cross country assessments of the effectiveness of policies using EUROMOD (e.g. Atkinson, Bourguignon, O’Donoghue, Sutherland and Utili, 2002) as well as earlier work pioneered with Bourguignon comparing policy effects in two countries, France and the UK, using national microsimulation models (Atkinson, Bourguignon and Chiappori, 1988a).

Much of the motivation behind his UK tax-benefit modelling work was to demonstrate how to reduce the extent of means-testing and its "twin failures" of high marginal tax rates created as benefits are withdrawn plus unmet need due to non take-up, while also reducing inequality and poverty. This involved the enhancement of social insurance and/or some form of basic income or guaranteed level of payment (e.g. Atkinson, King and Sutherland, 1983; Atkinson and Sutherland, 1988; Atkinson, 1995a; Atkinson, 2009).

Tony returned to this theme with great effect in his last book published before he died (Atkinson, 2015). Characteristically, his account of the budgetary and distributional effects of the alternative inequality-reducing policy packages that he advocated in this book includes a detailed explanation of the use of tax-benefit modelling for this purpose. This is a practical guide to understanding the calculations. It explains the importance of representative household micro-data combined with the detailed arithmetic modelling of policy rules, not only to assess the distributional effects but also to capture the net effects of changes to different parts of the tax-benefit system, which may interact. As always, Tony was explicit about the difficulties such as the need to be aware of, and adjust for, deficiencies in the micro-data and to account for the non take-up of means-tested benefits, especially if their effects are to be compared with those of non means-tested alternatives. In addition, he provides a principled justification of the static approach given the difficulties of, and uncertainty around, any comprehensive assessment of behavioural effects and the final incidence of policy changes.

Tony was enthusiastic about making sure that the models themselves were available, accessible and fast, with the idea that politicians, policy makers, journalists and advocates of reform should be able to analyse, debate and re-analyse the effects of possible policy changes in the privacy of their meeting rooms (or kitchen tables), before making public proposals. Tony encouraged me to write an "instruction manual" for those wanting to build their own models, which was published in this journal (Sutherland, 1991) and the UK models that we developed together, as well as EUROMOD, were designed to be made available to others. Meeting the challenges of doing so from negotiating suitable micro-data access conditions to resourcing the provision of a public good - 
has resulted in the creation of a community of users, helping to bridge the gaps between academic study and practical policymaking.

Tax-benefit microsimulation models are now widely - although still not comprehensively used for tax-benefit policy design and assessment in advanced economies, both inside and outside government. The same has yet to be achieved for lower income countries, where such calculations may be increasingly relevant, although some models exist and other initiatives have begun. The two essential inputs are the same now as they were in the early 1980s: high quality and accessible household micro-data and committed people with a dual appreciation of detail and the bigger picture, with ideas for reform proposals. Other things have changed, most notably technology, as Tony himself has illustrated: "My first tax-benefit model, constructed in 1968, was based on published tabulated data from the UK income tax records and required the most powerful computer then in Cambridge (an IBM System/360) located in the Institute of Astronomy. Turn-round time was 24 hours, and I used to cycle out to the Institute every evening, often to discover that I had made a coding error. Nonetheless, it produced simulation results for a variety of tax and benefit reforms and these formed the basis for Atkinson (1969a)" (EUROMOD, 2016, 3).

Exploiting further technological developments and the availability of micro-data of different kinds there is now plenty of scope to develop models for a wider range of policies and to push back the boundaries in terms of research questions to be addressed through linkage to other domains (macro-economic, psychological, spatial, longitudinal ...) (O’Donoghue, ed., 2014; Figari et al, 2015). However, some old challenges remain and may be particularly pertinent in countries new to tax-benefit modelling. As Tony would remind us, there is still room for improvement in micro-data and the adjustments that can be made for under-reporting and for missing top incomes and the non household populations (not typically captured by surveys); and the challenges of modelling non takeup of benefits, and non compliance generally, as well as the reconciliation with macro statistics remain with us. Among Tony's many legacies are communities of researchers ready to tackle these issues.

\section{Europe, by Eric Marlier and Brian Nolan}

Tony was deeply committed to Europe, and appalled - but not surprised - by Britain's vote in 2016 to leave the EU. He devoted a significant amount of his seemingly inexhaustible energy to progressing "Social Europe”.

Several distinct though inter-related strands may be distinguished in Tony's work related specifically to Europe. In the 1980s, through the European "Poverty Programmes", he was already strongly involved in pushing forward thinking about, and measurement of, poverty and social progress in Europe. His empirical work on income inequality often employed a comparative perspective (at the European or OECD-wide level as well as globally), and variation across countries was put front and centre in his teasing out of the drivers of inequality. A comparative framework was also key to the way he thought about the design and evaluation of tax and transfer policies and reforms; this was reflected in his own work and in his major role in the remarkably successful development of the EUROMOD tax-benefit model. Finally, he engaged very actively in debates about the development and direction of policy for the EU, seeing it as a very positive force in addressing poverty and inequality, even if not yet fulfilling its potential.

Looking back, one can see from the 1980s themes that were to feature strongly throughout in his subsequent work relating to Europe from Atkinson (1995b) and Atkinson (1998) to Atkinson (2013) and Atkinson, Guio and Marlier, eds. (2017). His emphasis on the need to define and measure poverty and inequality in a consistent fashion across countries and over time, insofar as possible, was crucial in the development of both research and statistical infrastructure at EU level. He consistently highlighted the importance of thinking through the conceptual basis for empirical measurement choices - for example, taking the household as the income-sharing unit, which may be problematic 
from a gender and minimum rights approach. The role that such measures should play in the policy process was also a common thread, emphasising that they should be accessible to all those concerned about poverty and inequality rather than solely to experts and civil servants. The role of institutions, norms and policy choices in understanding poverty and inequality, and the scope for countries to learn from one another while having their own institutional dynamics and values (through "contextualised benchmarking”), feature throughout. The imperative that poverty and inequality not be seen as concerns for social policy alone but be at the centre of policy across the span at both national and EU levels, including macroeconomic policy, was also a consistent theme.

Tony had a particular interest in and attachment to France, with an early comparative exercise focusing on tax and transfer policies in Britain and France (Atkinson, Bourguignon and Chiappori, 1988a; 1988b). His deep engagement with France led to appointment to the Conseil d'Analyse Economique advising the French Prime Minister and subsequently the award of the Légion d'Honneur. His research on inequality and poverty in Europe also extended to central and eastern European countries long before some of them joined the EU, investigating their experiences under Communism (Atkinson and Micklewright, 1992).

His contribution to improving EU's social monitoring was instrumental. It included leading, at the initiative of the Belgian Presidency of the EU, an academic report on indicators to monitor progress in fighting poverty and social exclusion across the EU on which we, together with Bea Cantillon of Antwerp University, collaborated. Typically, Tony's starting-point in approaching this task was to first think through the principles that should guide it, as for indicators to be fit for their intended purpose their construction needs to follow a principle-based approach. Also characteristically, it was then important to bring out the limitations of the available data and indicators and make concrete recommendations for their improvements, but "the best" was not to be "the enemy of the good" to allow progress to be made. The report (subsequently published as Atkinson, Cantillon, Marlier and Nolan, 2002) had a fundamental impact on the so-called Laeken indicators adopted by EU Heads of State and Government in 2001, and on the methodological framework which is still used today in the selection of the EU indicators in the field of social protection and social inclusion (Social Protection Committee, 2015).

This was given further impetus by a second academic report prepared by the same authors at the initiative of the EU Luxembourg Presidency in 2005. Published as Marlier, Atkinson, Cantillon and Nolan (2007), this inter alia highlighted the importance of properly capturing the situation of children through "children mainstreaming" and underpinned the subsequent development of a childspecific monitoring framework in the EU's suite (Social Protection Committee, 2008, 2012 and 2015; Guio et al., 2012; European Commission, 2013).

The framing and use of poverty targets was also something to which Tony gave considerable thought, both in discussing how the EU social indicators could be employed (for example in Atkinson, Marlier and Nolan, 2004) and subsequently when the EU agreed in 2010 to set a concrete social inclusion target in the context of the Europe 2020 strategy. Tony's approach to such perennial issues as the role of relative versus fixed poverty thresholds, country-specific versus EU-wide standards, and income versus multidimensional measures was typically nuanced, seeing value in a variety of approaches but always seeking to tease out their conceptual underpinnings and implications.

Tony regularly returned to the scope for EU initiatives. A proposal close to his heart was that each EU Member State should guarantee unconditionally to every child a basic income. The reason he puts forward is twofold: child poverty affects not only children's well-being at the moment when resources are insufficient, but also the capacity of children to build the required capabilities; this basic income would thus also be a social investment, contributing not only to the social inclusion Europe 2020 Headline Target but also to the education and employment Headline Targets (Atkinson and Marlier, eds., 2010a; see also Levy et al., 2013). 
Tony's commitment to advancing social monitoring and comparative socio-economic analysis in Europe was also reflected in his involvement in a range of EU-funded research collaborations, most recently the key role he played in the first and second Net-SILC networks bringing together data producers and users of the EU Statistics on Income and Living Conditions (Atkinson and Marlier, eds., 2010; Atkinson, Guio and Marlier, eds., 2017). Lessons from his work on social monitoring at EU level, in particular the principle-based approach, the architecture of indicators of poverty and social exclusion in a multinational context, and the contribution of indicators to the policy process, were also highly relevant in a global context, as brought out in Atkinson and Marlier (2010a, 2011) and Marlier and Atkinson (2010).

Tony of course saw his work that was not focused specifically on Europe as still having very direct relevance for Europe, and he also contributed over many years to high-level EU debates not only about "Social Europe" but also about official statistics and about macroeconomic and employment policies. With a characteristic refusal to follow conventional wisdom or accept the status quo, this led him to emphasise for example the importance of full employment and of setting this - alongside controlling inflation - at the centre of national and EU-level goals. In Atkinson (2015, 279) he notes that the European project has for considerable periods been dominated by the economic agenda, and that the Europe 2020 strategy can be validly criticised, but also highlights that the EU has been explicit in settings its goals "firmly in the direction of reducing poverty and inequality".

For us, as for others, working with Tony was both a privilege and a great pleasure, reflecting not only his remarkable intellect and deep social commitment but also his unfailing courtesy, good humour, friendship and kindness. "Putting People First...": he always did, in work and in life.

\section{Official statistics, by Walter J. Radermacher}

Tony was a scientist with great appreciation for official statistics, both in terms of statistical products and of their production. He was involved in many ways in official statistics at national, European and worldwide level, contributing to the creation of a culture of common measurement, within which things may be compared, because the categories and encoding procedures are identical.

"As the etymology of the word shows, statistics is connected with the construction of the state, with its unification and administration. ... This work is not only a subproduct of administrative activity, designed to further knowledge; it is also directly conditioned by its activity, as shown by the history of censuses, surveys ..., indexes, national accounting - all inseparable tools of knowledge and decision making. The link between description and management becomes clearly apparent when several states undertake - as is the case today with the EU - to harmonize their fiscal, social, and economic legislation ...” (Desrosières, 1998, 8).

Tony was very aware of the power of these (statistical) tools. He was interested in using this power for his scientific work. In addition, he wanted to help improve the quality of statistics by actively participating in further development, production and dissemination of official statistics. Tony also understood that the power to establish facts is associated with risks, vulnerabilities and responsibilities. For this reason, he worked for a modern governance of official statistics, which ensures independence, strength and innovation.

Because he knew about the meaning and power of facts, Tony was also keen to improve data literacy in our societies. In a sense, he saw earlier than many that inadequate education in, and knowledge of, statistics are the best breeding ground for so-called "post-truth politics". In times of the proliferation of data there is a risk that the particular logic of official statistics will be replaced by a general "data-logic", whereby quality differences are no longer seen as relevant, thus challenging the need to provide a public infrastructure for information (Davies, 2017). At such times, we already miss Tony's influence, advice and voice.

A few examples show Tony's work more specifically. 
In the first place, of course, it was important to him to improve official statistics, where they coincided with his own research interests. Tony was a key participant in the Networks for the Analysis of EU-SILC (Net-SILC from 2008 to 2010 and NetSILC2 from 2011 to 2015), which were ambitious cooperation platforms bringing together expertise from both data producers (directly involved in the collection of EU-SILC data) and data users (a third Network was launched in 2016). He was the scientific backbone of these projects and with his precious advice, the patient revision of the work and his constant guidance, he allowed the achievement of some remarkable successes. In particular, he was the co-editor of the report of Net-SILC that contains recommendations for both the statistical process and the use of indicators for European social policies: "Under the principle of subsidiarity, Member States are free to set their national (outcome) targets on the basis of what they consider the most appropriate indicators given their national circumstances and priorities. Setting targets is a difficult area for a combination of political and scientific reasons. Indeed, to be truly meaningful these targets need to be evidence-based and they should be the result of a rigorous diagnosis of the causes of poverty and social exclusion in the country" (Atkinson and Marlier, 2010b, 31). More recently, Tony wrote three chapters for the final publication of NetSILC2 (Atkinson, Guio and Marlier, 2017a, 2017b; Aaberge, Atkinson and Sigstad, 2017). He was also the reviewer of all the chapters of those publications, making them of extremely high quality. Several of the projects he contributed to initiating are now in regular statistical production or on the way of being implemented. The EUROMOD microsimulation model is a prominent example of such successes. EUROMOD was initiated for research purposes (Atkinson, 2005b) and is now on the way to becoming a standard tool for policy analysis and statistics via e.g. the flash estimates of income. Tony also participated in EU-SILC bi-annual conferences. In the preparation for the DGINS conference 2016 on Income, Consumption and Wealth Statistics (Statistics Austria 2016) he was considered as the best possible keynote speaker; unfortunately his health conditions did not allow him to play this role.

Tony's deep knowledge of public economics issues was also called upon when the UK Office for National Statistics wanted to develop its work on better measuring the output of government services. This had both statistical and political dimensions, given the focus of the UK government on quantifying government outputs and productivity. His eventual report (Atkinson, 2005a) represented a major and meticulous study across a broad range of government services, making the case for measuring outputs rather than inputs and for taking the quality of government services into account. It gave strong conceptual and practical support to the discussion of these issues at European level, and the eventual adoption of National Accounts standards in Europe (the ESA 2010; see European Parliament and Council of the European Union, 2013) included the requirement that health and education services be compiled through direct output measurement.

Between 2009 and 2012 Tony was a member of the first European Statistical Governance Advisory Board (ESGAB) that was mandated to strengthen and supervise Eurostat and the European Statistical System (ESS). The establishment of this Board was an important component in a package of new institutional arrangements designed to react to weaknesses in the quality of national statistical data: "An unprecedented economic crisis has left the ESS with the challenge of responding to the new statistical demands at a time when resources are coming under increased pressure. What is more, the trustworthiness of official statistics in general has been called into question as a consequence of the misreporting of public finance statistics by Greece. It has become clear that proper implementation of the principles enshrined in the Code of Practice is vital and that loss of credibility in the official statistics of one country affects the credibility of the ESS as a whole" (ESGAB, 2010, 4).

In this extremely critical phase it was crucial for Eurostat, and for me as its Director General, to have an experienced professional like Tony at our side. His advice was always wise and well balanced. With his deep understanding of the DNA of official statistics, he was the best partner and friend one could wish to have. 


\section{References}

Aaberge, R., A. B. Atkinson and H. Sigstad, "Income poverty, affluence and polarisation viewed from the median," in Atkinson, Guio and Marlier (eds.), 101-120, 2017.

Aaberge, R., and A. Brandolini, "Multidimensional Poverty and Inequality," in Atkinson and Bourguignon (eds.), 141-216, 2015.

Acemoglu, D., “Localized and Biased Technologies: Atkinson and Stiglitz’s New View, Induced Innovations, and Directed Technological Change,” Economic Journal, 125, 443-57, 2015.

Alkire, S., and J. E. Foster, “Counting and Multidimensional Poverty Measurement," Journal of Public Economics, 95, 476-487, 2011.

Alvaredo, F., A. B. Atkinson, T. Piketty, E. Saez, “The Top 1 Percent in International and Historical Perspective,” Journal of Economic Perspectives, 27, 3-20, 2013.

Alvaredo, F., L. Chancel, T. Piketty, E. Saez and G. Zucman, “Global Inequality Dynamics: New Findings from WID.world,” NBER Working Paper No. 23119, 2017.

Arrow, K. J., Social Choice and Individual Values, Wiley, New York, 1951.

Atkinson, A. B., Poverty in Britain and the Reform of Social Security, Cambridge University Press, Cambridge, 1969a.

Atkinson, A. B., “The Timescale of Economic Models: How Long is the Long Run?,” Review of Economic Studies, 36, 137-52, 1969b.

Atkinson, A. B., “On the Measurement of Inequality,” Journal of Economic Theory, 2, 244-263, 1970.

Atkinson, A. B., “The Measurement of Economic Mobility,” in P. J. Eigjelshoven and L. J. van Gemerden (eds.), Inkomensverdeling en openbare financien - Essays in Honour of Jan Pen, 924, Het Spectrum, Utrecht, 1981a.

Atkinson, A. B., “On Intergenerational Income Mobility in Britain,” Journal of Post Keynesian Economics, 13, 194-218, 1981b.

Atkinson, A. B., Social Justice and Public Policy, Harvester-Wheatsheaf, 1983a.

Atkinson, A. B., "Intergenerational Earnings Mobility in Britain,” in W. Schmähl (ed.), Ansätze der Lebenseinkommensanalyse, 56-72, Mohr, Tübingen, 1983b.

Atkinson, A. B., "On the Measurement of Poverty,” Econometrica, 55, 749-764, 1987.

Atkinson, A. B., "The Take-Up of Social Security Benefits,” in A. B. Atkinson, Poverty and Social Security, 190-207, Harvester Wheatsheaf, Hemel Hempstead, 1989.

Atkinson, A. B., "Public Economics and the Economic Public," European Economic Review, 34, 225-248, 1990a.

Atkinson, A. B., “Introduction,” in T. M. Smeeding, M. O’Higgins and L. Rainwater (eds.), Poverty, Inequality, and Income Distribution in Comparative Perspective: The Luxembourg Income Study (LIS), xvii-xxv, Harvester Wheatsheaf, Hemel Hempstead, 1990b.

Atkinson, A. B., "Income Maintenance for the Unemployed in Britain and the Response to High Unemployment," Ethics, 100, 569-585, 1990c.

Atkinson, A. B., "Measuring Poverty and Differences in Family Composition,” Economica, 59, 116, 1992a.

Atkinson, A. B., "Institutional Features of Unemployment Insurance and the Working of the Labour Market,” in P. Dasgupta, D. Gale, E. Maskin and O. Hart (eds.), Economic Aspects of Markets and Games, 82-106, MIT Press, Cambridge, 1992b.

Atkinson A. B., Public Economics in Action. The Basic Income/Flat Tax Proposal, Oxford University Press, Oxford, 1995a.

Atkinson, A. B., Incomes and the Welfare State: Essays on Britain and Europe, Cambridge University Press, Cambridge, 1995b. 
Atkinson, A. B., “On Targeting and Family Benefits,” in A. B. Atkinson, Incomes and the Welfare State: Essays on Britain and Europe, 223-261, Cambridge University Press, Cambridge, 1995c.

Atkinson, A. B., "Bringing Income Distribution in from the Cold,” Economic Journal, 107, 297-321, 1997.

Atkinson, A. B., Poverty in Europe, Blackwell, Oxford, 1998.

Atkinson, A. B., The Economic Consequences of Rolling Back the Welfare State, MIT Press, Cambridge, 1999.

Atkinson, A. B., "Multidimensional Deprivation: Contrasting Social Welfare and Counting Approaches," Journal of Economic Inequality, 1, 51-65, 2003.

Atkinson, A. B., Atkinson Review: Final report - Measurement of Government Output and Productivity for the National Accounts, Palgrave Macmillan, Basingstoke, 2005a.

Atkinson, A. B., "EUROMOD and the Development of EU Social Policy,” EUROMOD Working Paper, EM1/05, 2005b.

Atkinson, A. B., The Changing Distribution of Earnings in OECD Countries, Oxford University Press, 2008a.

Atkinson, A. B., “More on the Measurement of Inequality,” Journal of Economic Inequality, 6, 277283, (written in 1973), 2008b.

Atkinson, A. B., “An Enlarged Role for Tax-Benefit Models”, in O. Lelkes and H. Sutherland (eds.), Tax and Benefit Policies in the Enlarged Europe: Assessing the Impact with Microsimulation Models, 33-46, Ashgate, Farnham, 2009.

Atkinson, A. B., "Part II: Putting People First and Macro-economic Policy,” in A. B. Atkinson, "Ensuring Social Inclusion in Changing Labour and Capital Markets,” European Economy, Economic Papers, 481, 39-64, European Commission, Brussels, 2013.

Atkinson, A. B., Public Economics in an Age of Austerity, Routledge, Abingdon-on-Thames, 2014.

Atkinson, A. B., Inequality: What can be done?, Harvard University Press, Cambridge, 2015.

Atkinson, A. B., Monitoring Global Poverty: Report of the Commission on Global Poverty, World Bank, Washington, 2017.

Atkinson, A. B., and F. Bourguignon, "The Comparison of Multi-Dimensioned Distributions of Economic Status,” Review of Economic Studies, 49, 183-201, 1982.

Atkinson, A. B., and F. Bourguignon, "Income Distribution and Differences in Needs," in G. R. Feiwel (ed.), Arrow and the Foundations of the Theory of Economic Policy, 350-370, Macmillan, London, 1987.

Atkinson, A. B., and F. Bourguignon, "Introduction: Income Distribution and Economics," in Atkinson and Bourguignon (eds.), 1-58, 2000a.

Atkinson, A. B., and F. Bourguignon, "Poverty and Inclusion from a World Perspective," in Governance, Equity and Global Markets, 179-192, La Documentation Française, Paris, 2000b.

Atkinson, A. B., and F. Bourguignon (eds.), Handbook of Income Distribution, Volume 1, North Holland, Amsterdam, 2000.

Atkinson, A. B., and F. Bourguignon (eds.), Handbook of Income Distribution, Volume 2, North Holland, Amsterdam, 2015.

Atkinson, A. B., F. Bourguignon and P.-A. Chiappori, "What Do We Learn about Tax Reform from International Comparisons? France and Britain,” European Economic Review, 32, 343 - 352, 1988a.

Atkinson, A. B., F. Bourguignon and P.-A. Chiappori, “The French Tax-Benefit System, and a Comparison with the British System,” in A. B. Atkinson and H. Sutherland (eds.), Tax-Benefit Models, STICERD Occasional Paper, 10, LSE, London, 1988b.

Atkinson, A. B., F. Bourguignon, C. O’Donoghue, H. Sutherland and F. Utili, "Microsimulation of Social Policy in the European Union: Case Study of a European Minimum Pension," Economica, 69, 229-243, 2002. 
Atkinson, A. B., and A. Brandolini, "Promise and Pitfalls in the Use of 'Secondary' Data-sets: Income Inequality in OECD Countries,” Journal of Economic Literature, 39, 771-799, 2001.

Atkinson, A. B., and A. Brandolini, "On Data: a Case Study of the Evolution of Income Inequality across Time and across Countries," Cambridge Journal of Economics, 33, 381-404, 2009.

Atkinson, A. B., and A. Brandolini, “On Analyzing the World Distribution of Income,” World Bank Economic Review, 24, 1-37, 2010.

Atkinson, A. B., and A. Brandolini, "Unveiling the Ethics behind Inequality Measurement: Dalton's Contribution to Economics,” Economic Journal, 125, 209-220, 2015.

Atkinson, A. B., B. Cantillon, E. Marlier and B. Nolan, Social Indicators: The EU and Social Inclusion, Oxford University Press, Oxford, 2002.

Atkinson, A. B., A.-C. Guio and E. Marlier, "Monitoring Social Europe ,” in Atkinson, Guio and Marlier (eds.), 31-47, 2017a.

Atkinson, A. B., A.-C. Guio and E. Marlier, "Monitoring the evolution of income poverty and real incomes over time," in Atkinson, Guio and Marlier (eds.), 63-85, 2017b.

Atkinson, A. B., A.-C. Guio and E. Marlier (eds.), Monitoring social inclusion in Europe, Publications Office of the European Union, Luxembourg, 2017.

Atkinson, A. B., and A. Harrison, Distribution of Personal Wealth in Britain, Cambridge University Press, Cambridge, 1978.

Atkinson, A. B., and S. P. Jenkins, "The Steady-State Assumption and the Estimation of Distributional and Related Models,” Journal of Human Resources, 19, 358-376, 1984.

Atkinson, A. B., M. A. King and H. Sutherland, "The Analysis of Personal Taxation and Social Security,” National Institute Economic Review, 103, 63-74, 1983.

Atkinson, A. B., and E. Marlier, “Analysing and Measuring Social Inclusion in a Global Context,” Report ST/ESA/325 produced at the request of the United Nations, Department of Economic and Social Affairs (UNDESA), United Nations, New York, 2010a.

Atkinson, A. B., and E. Marlier, "Human Development and Indicators of Poverty and Social Exclusion as Part of the Policy Process,” Indian Journal of Human Development, 5, 293-320, 2011.

Atkinson, A. B., and E. Marlier, "Living conditions in Europe and the Europe 2020 agenda," in Atkinson and Marlier (eds.), 21-35, 2010b.

Atkinson, A. B., and E. Marlier (eds.), Income and Living Conditions in Europe, Publications Office of the European Union, Luxembourg, 2010.

Atkinson, A. B., E. Marlier and B. Nolan, "Indicators and Targets for Social Inclusion in the EU,” Journal of Common Market Studies, 42, 47-75, 2004.

Atkinson, A. B., A. K. Maynard and C. G. Trinder, Parents and Children: Incomes in Two Generations, Heinemann Educational Books, London, 1983a.

Atkinson, A. B., A. K. Maynard and C. G. Trinder, "Evidence on Intergenerational Income Mobility in Britain: Some Further Preliminary Results,” in B. Weisbrod and H. Hughes (eds.), Human Resources, Employment and Development. Volume 3: The Problems of Developed Countries and the International Economy, 290-308, Macmillan, London, 1983b.

Atkinson, A. B., and J. Micklewright, "On the Reliability of Income Data in the Family Expenditure Survey 1970-1977,” Journal of the Royal Statistical Society Series A, 146 Part 1, 33-61, 1983.

Atkinson, A. B., and J. Micklewright, "Unemployment Compensation and Labor Market Transitions: A Critical Review,” Journal of Economic Literature, 29, 1679-1727, 1991.

Atkinson, A. B., and J. Micklewright, Economic Transformation in Eastern Europe and the Distribution of Income, Cambridge University Press, Cambridge, 1992.

Atkinson, A. B., and T. Piketty (eds.), Top Incomes over the Twentieth Century: A Contrast between Continental European and English-Speaking Countries, Oxford University Press, Oxford, 2007.

Atkinson, A. B., and T. Piketty (eds.), Top Incomes : A Global Perspective, Oxford University Press, Oxford, 2010. 
Atkinson, A. B., T. Piketty and E. Saez, “Top Incomes in the Long Run of History,” Journal of Economic Literature, 49, 3-71, 2011.

Atkinson, A. B., L. Rainwater and T. M. Smeeding, Income Distribution in OECD Countries: The Evidence from the Luxembourg Income Study (LIS), Organization for Economic Co-operation and Development, Paris, 1995.

Atkinson, A. B., and N. H. Stern, "Pigou, taxation and public goods," Review of Economics Studies, 41, 119-128, 1972.

Atkinson, A. B., and J. E. Stiglitz, “A New View of Technological Change,” Economic Journal, 79, 573-578, 1969.

Atkinson, A. B., and J. E. Stiglitz, “The structure of indirect taxation and economic efficiency.” Journal of Public Economics, 1, 97-119, 1972.

Atkinson, A. B., and J. E. Stiglitz, "The Design of Tax Structure: Direct Versus Indirect Taxation,” Journal of Public Economics, 6, 55-75, 1976.

Atkinson, A. B., and J. E. Stiglitz, Lectures on Public Economics, McGraw-Hill, Maidenhead, 1980. (Updated edition: Princeton University Press, Princeton, 2015.)

Atkinson, A. B., and H. Sutherland (eds.), Tax Benefit Models, STICERD Occasional Paper, 10, 1988.

Atkinson, A. B., C. G. Trinder and A. K Maynard, "Evidence on Intergenerational Income Mobility in Britain,” Economics Letters, 1, 383-388, 1978.

Böhlmark, A., and M. J. Lindquist, "Life-Cycle Variations in the Association between Current and Lifetime Income: Replication and Extension for Sweden,” Journal of Labor Economics, 24, 879-896, 2006.

Buchanan, J. M., “The Theory of Public Finance,” Southern Economic Journal, 26, 234-238, 1960.

Chadwick, L., and G. Solon, "Intergenerational Income Mobility Among Daughters,” American Economic Review, 92, 335-344, 2002.

Chen, S., and M. Ravallion, "The Developing World is Poorer than we Thought, but no Less Successful in the Fight against Poverty,” Quarterly Journal of Economics, 125, 1577-1625, 2010.

Dalton, H., "The measurement of the inequality of incomes," Economic Journal, 30, 348-361, 1920.

Davies, W., "How statistics lost their power - and why we should fear what comes next," The Guardian, 19 January 2017.

Desrosières, A., The Politics of Large Numbers - A History of Statistical Reasoning, Harvard University Press, Cambridge, 1998.

Diamond, P. A., and J. A. Mirrlees, "Optimal Taxation and Public Production I: Production Efficiency,” American Economic Review, 61, 8-27, 1971a.

Diamond, P. A., and J. A. Mirrlees, “Optimal Taxation and Public Production II: Tax Rules,” American Economic Review, 61, 261-278, 1971b.

ESGAB (European Statistical Governance Advisory Board), Second annual report to the European Parliament and the Council on the implementation of the European Statistics Code of Practice by Eurostat and the European Statistical System as a whole, ESGAB, http://ec.europa.eu/eurostat/documents/34693/39285/EN-ESGAB-report-2010-FINAL, 2010.

EUROMOD, Celebrating 20 Years of EUROMOD, Colchester, https://www.euromod.ac.uk/sites/default/files/euromod-20/EUROMOD-Celebrating-20years.pdf, 2016.

European Commission, “Commission Recommendation of 20 February 2013 - Investing in Children: breaking the cycle of disadvantage, 2013/112/EU,” Official Journal of the European Union, http://eur-lex.europa.eu/legalcontent/EN/TXT/PDF/?uri=CELEX:32013H0112\&from=EN, 2013.

European Parliament and Council of the European Union, "Regulation (EU) no 549/2013 of the European Parliament and of the Council of 21 May 2013 on the European system of national and 
regional accounts in the European Union,” Official Journal of the European Union, http://eurlex.europa.eu/legal-content/en/TXT/PDF/?uri=CELEX:32013R0549, 2013.

Ferreira, F. H. G., S. Chen, A. Dabalen, Y. Dikhanov, N. Hamadeh, D. Jolliffe, A. Narayan, E. B. Prydz, A. Revenga, P. Sangraula, U. Serajuddin and N. Yoshida, "A Global Count of the Extreme Poor in 2012: Data Issues, Methodology and Initial Results,” Journal of Economic Inequality, 14, 141-172, 2016.

Figari, F., A. Paulus and H. Sutherland, "Microsimulation and Policy Analysis," in Atkinson and Bourguignon (eds.), 2141-2221, 2015.

Foster, J. E., and A. F. Shorrocks, "Poverty orderings,” Econometrica, 56, 173-177, 1988.

Galton, F., "Regression Towards Mediocrity in Hereditary Stature,” Journal of the Anthropological Institute, 15, 246-63, 1886.

Gini, C., "Measurement of inequality of incomes,” Economic Journal, 31, 124-126, 1921.

Grawe, N. D., “Lifecycle bias in estimates of intergenerational earnings persistence,” Labour Economics, 13, 519-664, 2006.

Guio, A.-C., D. Gordon and E. Marlier, "Measuring material deprivation in the EU: Indicators for the whole population and child-specific indicators,” Eurostat Methodologies and Working Papers, 2012.

Haider, S., and G. Solon, "Life-Cycle Variation in the Association between Current and Lifetime Earnings,” American Economic Review, 96, 1308-1320, 2006.

Harberger, A. C., "The Incidence of the Corporation Income Tax,” Journal of Political Economy, 70, 215-240, 1962.

Jäntti, M., and S. P. Jenkins, “Income mobility,” in Atkinson and Bourguignon (eds.), 807-935, 2015.

Jenkins, S. P., “Snapshots versus Movies: 'Lifecycle Biases' and the Estimation of Intergenerational Earnings Inheritance,” European Economic Review, 31, 1149-1158, 1987.

Jenkins, S. P., “Anthony B. Atkinson (1944-),” in R. Cord (ed.), The Palgrave Companion to Cambridge Economics, 1151-1174, Palgrave Macmillan, Basingstoke, 2017.

Jenkins, S. P., and P. J. Lambert, “Ranking income distribution when needs differ,” Review of Income and Wealth, 39, 337-356, 1993.

Jolliffe, D., and E. B. Prydz, "Societal Poverty: A Relative and Relevant Measure,” World Bank Policy Research Working Paper, 2017.

Kolm, S.-C., "The Optimal Production of Social Justice,” in J. Margolis and H. Guitton (eds.), Public Economics. An Analysis of Public Production and Consumption and Their Relations to the Private Sectors, 145-200, Macmillan, London, 1969.

Kolm, S.-C., “Unequal inequalities,” Journal of Economic Theory, 12, 416-442, 13, 82-111, 1976.

Kuznets, S., Shares of Upper Income Groups in Income and Savings, National Bureau of Economic Research, New York, 1953

Levy, H., M. Matsaganis and H. Sutherland, "Towards a European Union Child Basic Income? Within and between country effects,” EUROMOD Working Paper, EM 6/13, 2013.

Marlier, E., and A. B. Atkinson, "Indicators of Poverty and Social Exclusion in a Global Context," Journal of Policy Analysis and Management, 29, 285-304, 2010.

Marlier, E., A. B. Atkinson, B. Cantillon, and B. Nolan, The EU and social inclusion: Facing the challenges, Policy Press, Bristol, 2007.

Musgrave, R. A., The Theory of Public Finance: A Study in Public Economy, McGraw-Hill, New York, 1959.

O’Donoghue, C., (ed.), Handbook of Microsimulation Modelling, Emerald Group Publishing Limited, Bingley, 2014.

Piacquadio, P., “A Fairness Justification of Utilitarianism,” Econometrica, forthcoming.

Ramsey, F. P., “A Contribution to the Theory of Taxation,” Economic Journal, 37, 47-61, 1927. 
Ravallion, M., and S. Chen, “Weakly Relative Poverty,” Review of Economics and Statistics, 93, 1251-1261, 2011.

Ravallion, M., and S. Chen, “A Proposal for Truly Global Poverty Measures,” Global Policy, 4, 258-265, 2013.

Ravallion, M., G. Datt and D. van de Walle, “Quantifying Absolute Poverty in the Developing World,” Review of Income and Wealth, 37, 345-361, 1991.

Rowntree, S., and G. R. Lavers, Poverty and the Welfare State, Longman Green, London, 1951.

Samuelson, P. A., "The Pure Theory of Public Expenditure,” Review of Economics and Statistics, 36, 387-389, 1954.

Sandmo, A., "Tony Atkinson 1944-2017: A lifetime commitment to the study of inequality," European Journal of the History of Economic Thought, 24, 612-623, 2017.

Sen, A. K., “Poor, Relatively Speaking,” Oxford Economic Papers, 35, 153-169, 1983.

Social Protection Committee, Child Poverty and Well-Being in the EU: Current status and way forward, European Commission, Brussels, 2008.

Social Protection Committee, SPC advisory report to the European Commission on tackling and preventing child poverty, promoting child well-being, European Commission, Brussels, 2012.

Social Protection Committee, Portfolio of EU Social Indicators for the monitoring of progress towards the EU objectives for social protection and social inclusion 2015 Update, European Commission, Brussels, 2015.

Solon, G., "Biases in the Estimation of Intergenerational Earnings Correlations," Review of Economics and Statistics, 71, 172-174, 1989.

Solon, G., "Intergenerational Income Mobility in the United States," American Economic Review, 82, 393-408, 1992.

Statistics Austria, “DGINS 2016 - Statistics on Income, Consumption, Wealth”, Statistics Austria, http://www.dgins2016.at/, 2016.

Sutherland, H., “Constructing a Tax-Benefit Model: What Advice Can One Give?,” Review of Income and Wealth, 37, 199-219, 1991.

Sutherland, H., and F. Figari, "EUROMOD: the European Union tax-benefit microsimulation model" International Journal of Microsimulation, 6, 4-26, 2013.

Tiebout, C. M., “A Pure Theory of Local Expenditures,” Journal of Political Economy, 64, 416-424, 1956.

Von Neumann, J., and O. Morgenstern, Theory of Games and Economic Behavior, Princeton University Press, Princeton, 1944.

Weymark, J., “Generalized Gini Inequality Indices,” Mathematic Social Sciences, 1, 409-430, 1981.

World Bank, Purchasing Power Parities and the Real Size of World Economies: A Comprehensive Report of the 2011 International Comparison Program, World Bank Publications, Washington, 2015.

Yaari, M., “The Dual Theory of Choice under Risk,” Econometrica, 55, 95-115, 1987. 


\section{Statistics Norway}

Postal address:

PO Box 8131 Dept

NO-0033 Oslo

Office address:

Akersveien 26, Oslo

Oterveien 23, Kongsvinger

E-mail: ssb@ssb.no

Internet: www.ssb.no

Telephone: + 4762885000

ISSN: 1892-753X 